Further protests planned at Seabrook nuclear plant

New protests are being planned at the controversial Seabrook nuclear power plant-on the coast of New Hampshire -following last week's decision by the Nuclear Regulatory Agency to withdraw a ban on further construction work.

The ban, imposed last month, followed criticisms that the Environmental Protection Agency had adopted incorrect procedures in approving the 2.3 megawatt power station's proposed cooling system, which will involve discharging hot water into the sea.

Environmental groups which had opposed the scheme on the grounds that it would seriously damage the local marine life, had claimed the NRC's decision to suspend construction as a "major victory".

However with a speed that took many opponents by surprise--a decision had not been expected until midSeptember-the EPA announced on 4 August that it had reconsidered the proposed cooling system, and still considered that it complied with federal water pollution laws.

Six days later the NRC, which had previously voted $2-1$ to suspend construction, voted unanimously that the EPA's approval eliminated the conditions which had led to the suspension, and that work at the site could therefore continue.

Opponents of the Seabrook plant, which has become a national symbol

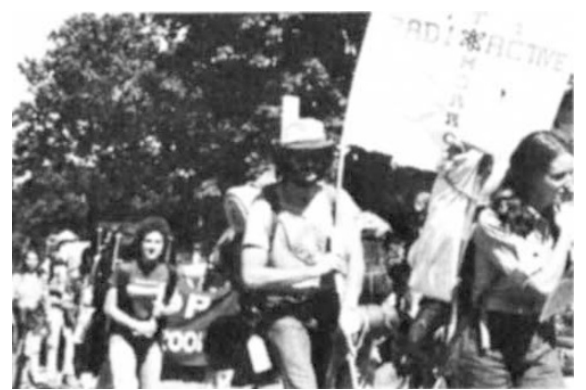

for the antinuclear movement and attracted a 10,000-strong, four-day demonstration in June, claimed that the EPA's decision had been made "with unprecedented haste in a politically charged atmosphere". A procedural suit has already been filed against both the NRC and the EPA by an attorney representing the two antinuclear groups that put together the Clamshell Alliance of several protesting organisations.

The NRC's decision has been welcomed by the Public Service Company of New Hampshire, the utility company which has already spent $\$ 400$ million on construction work at the Seabrook site, and had to lay off 1,800 workers.

However members of the Clamshell alliance are already preparing new protest plans. "Many different groups within the Clamshell Alliance will demonstrate their opposition to the ruling through a series of non-violent civil disobedience actions", said one member. Possible actions could include both further sit-ins at the site, where 1,400 demonstrators were arrested last summer, and a blockade by small boats of the vessels used to transport the main reactor components.

\section{Antibiotics may stay in US animal feed}

THE US Food and Drug Administration announced last week that it is delaying -and may eventually drop--proposals published earlier in the year to limit the distribution of animal feed premixes and medicated feeds containing the antibiotics penicillin, chlortetracycline and oxytetracycline.

The proposal would have limited the distribution of such feed-mixes to feed mills which had been specially approved, and to the order of a licensed veterinarian. It followed earlier announcements by the FDA commissioner that he intended to eliminate the use of antibiotics in animal feeds because of the possible danger of the transference of antibiotic resistance. concerns that have led to a similar ban in Britain and other European countries following the Swann Report of 1970.

However such moves have been consistently opposed by the pharmaceutical and agricultural industries, the former claiming that it would lead to substan- tial loss of sales, the latter that the extra food necessary to compensate for the withdrawal of antibiotics would push up the price of agricultural products.

In last week's announcement, Dr Kennedy says that since the January proposals were published, a number of concerns have been expressed by the public which need to be evaluated further.

These concerns include the contention that the number, distribution and kinds of veterinarians available are not adequate to diagnose and write the prescriptions under the proposed requirement, and assertions that the proposal will unnecessarily restrict the practice of veterinary medicine because it will eliminate flexibility in the dosage levels available to be prescribed.

The commissioner says that because of these and other concerns, he is considering "whether the proposals should be withdrawn or revised to better address the public's concerns".

\section{Shadow of '68 still hangs over Czech science}

TEN years ago this month, the ap1 pearance of Soviet tanks in the streets of Prague brought the Dubcek spring to a sudden and violent end. As well as occupying such strategic points as the Central Telegraph Office and the editorial premises of leading newspapers, the "fraternal" invaders took particular care to take possession of the building of the Czechoslovak Academy of Sciences.

So important was the occupation of the academy to them that the officer, a first lieutenant, who commanded the platoon which "seized the ... building and organised its security and defence", ordering out the rightful occupants with an abrupt message in Russian (see caption), was subsequently recommended for the order of the Red Star.

The physical, though temporary, occupation of the Academy was followed, in due course, by administrative measures curtailing its freedom. As part of the post-1968 "normalisation", new statues were imposed on the academy, depriving it of much of its former autonomy and downgrading the qualifications required of its leading officials.

From 1970 vice-chairmen no longer had to be full members of the academy, and the general secretary need not even be a member. The chairman of the academy Dr Frantisek Sorm was dismissed, and replaced by one of the vice-chairmen, Jaroslav Kozesnik. Two new vice-chairmen were nominated by the government. and a new general secretary, Karel Friml, appointed, who did not hold a postgraduate degree. Scientists working at the academy lost their security of employment; their contracts were limited to four years.

Annual statistical handbooks reveal that the early 1970s were black years for Czechoslovak learning. Numbers of new graduates steadily rose from 1,200 a year to 1,516 a year between 1966 and 1969 , but then fell sharply to 906 in 1970 and 875 in 1977. The figure remained at around 1,100-1,200 for the next four years and only in 1976 fully recovered to 1,504 .

It was at the academy level, however, that the new measures were most severely felt. Ideological purity was emphasised above academic prowess. The new director of the Institute of Nuclear Physics, Jaroslav Prochazka, expressed this trend in the nownotorious saying: "I would throw out even Einstein if his political views 


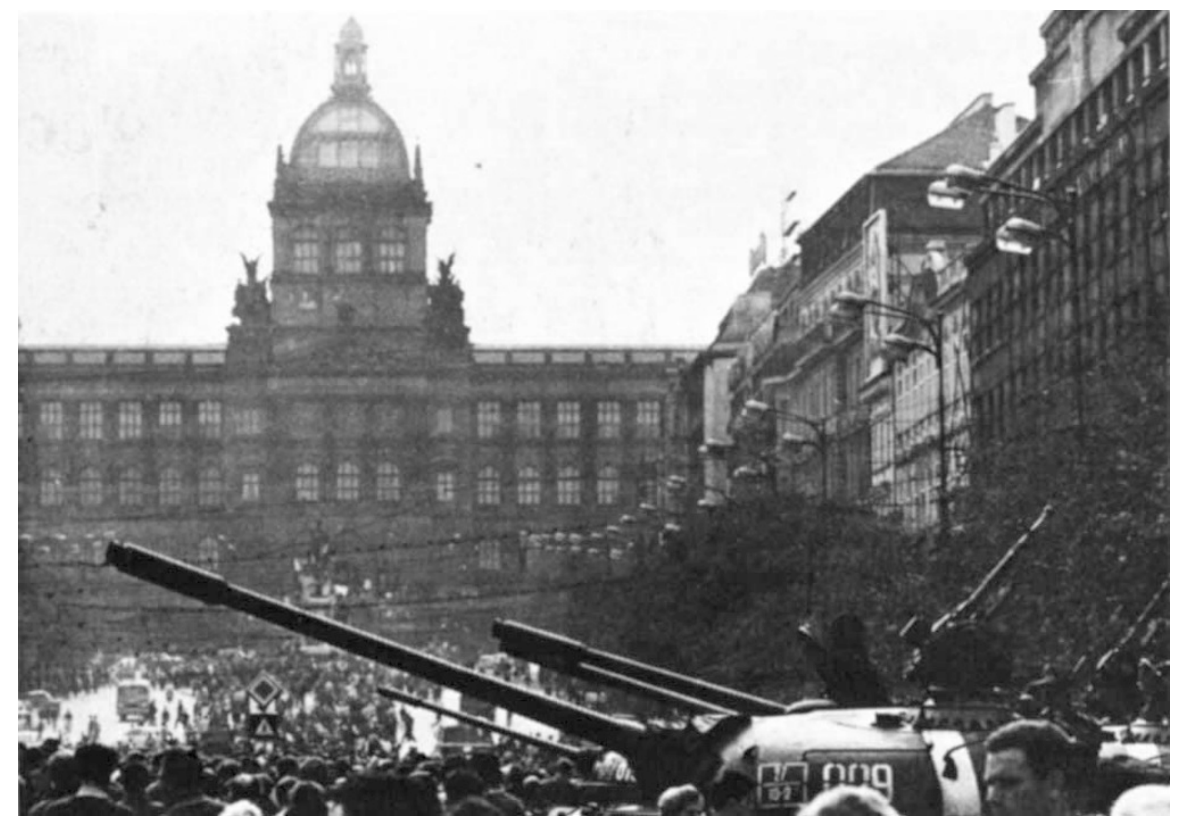

Prague, August 1968. The Academy of Science was closed with this order: "I, First Lieutenant Yurii Aleksandrovich Orlov, representing the Warsaw Pact troops, order all workers and members of the Czechoslovak Academy of Sciences to cease work by 13.00 hours, 22 August, and to evacuate all premises of the Czechoslovak Academy of Sciences."

were not quite in order!" The same sentiment was expressed more formally in the official Vestnik (Bulletin) of the academy that "the final appointment to the post of institute directors will be made according to the designated list and in close association with the Party organs".

In 1977, all academy members had to complete an affidavit relating not only to their own political reliability but that of their relatives and in-laws.

Scientists who failed to satisfy these political criteria were kept in work on contracts so short as to suggest scientific piecework-and often, ultimately, driven into premature retirement. By 1974, it would seem that the losses to science due to post-1968 repression and emigration were causing serious shortages of personnel.

At the May Plenum of the Central Committee of the Communist Party of Czechoslovakia, which laid considerable stress on the scientific-andtechnological development of the national economy, a resolution was passed which appeared to extend forgiveness to the hundreds of scientists and technologists who had been excluded from professional work due to political "black marks" from 1968. The wording of the resolution stressed however, that this second chance was being offered only to those "who today recognize their mistakes and by their positive efforts are proving their relationship to our society and contribute to its development".
Not surprisingly, many of the bolder spirits ignored the offer. By 1975, reports were reaching the West that still tens of thousands of scientists and artist, were barred from professional activity, and that a new wave of police searches of the homes of former scientists was in full swing. New legislation, it was reported, would curtail the powers and responsibilities of university rectors and facilitate the dismissal of politically "unreliable" individuals.

The effect of such measures on Czechoslovak science has been considerable. During the 1970's Czechoslovak participation in international conferences has fallen off drastically and, although according to Comecon statistics, Czechoslovakia plays a major role in the joint nuclear research programme, in 1973 and 1974 there was no Czechoslovak representation at all at two international nuclear physics conferences.

Publication, even at home, is drastically controlled; publication in a Western country is often dependent on previously having published papers in a Soviet journal-a condition hard to fulfil in view of the lag in Soviet publication schedules.

Access to western journals is severely limited. According to Professor Frantisek Janouch, now working at the Stockholm Institute of Nuclear Physics, in 1974 some 14 issues of Nature were confiscated by the authorities ("withdrawal of the right to delivery" is the official euphemism for this practice).

Not surprisingly, many former Czech scientists see these restrictions as disastrous. According to microbiologist Ivan Malek, prior to 1968 a member of the Central Committee of the Party, these measures "brought Czechoslovak science to its knees in recent years"; and are likely to bring about a state of "catastrophic backwardness". Even scientific cooperation within Comecon, he maintained, "which ought at least to redress the opportunities that have been spoiled, is not developing in conformity with the needs and the real character of science. It has not been able to free itself from heavy bureaucratic formalism."

Malek delivered that message in 1975. Since then Czechoslovak science has had what might be seen as one relieving factor in a vista of otherwise mediocrity - the participation of Vladimir Remek in the first "international" Comecon space-flight. Yet it is perhaps significant that the Czech media stressed throughout the "close cooperation" with the Soviet Union, and the fact that the Soviet Union bore some $95 \%$ of the cost. (The Poles, on the other hand greeted the flight of their representative by stressing the specifically Polish contribution.)

Nor is this emphasis on Soviet aid an isolated instance. Dr Eva Dubska, a psychiatrist, who emigrated from Czechoslovakia last year, reports that the peculiar theories of Academician Snezhnevskii, the Soviet psychiatrist who attributes all mental illness (and for that matter, political opposition) to schizophrenia, are being increasingly introduced into $\mathrm{Czech}$ psychiatric theory.

After a decade of political pressure, it is not perhaps surprising that only slightly more than $10 \%$ of the original signatories of Charter 77 were scientists or technologists. Zdenek Mlynar, a prominent Chartist, told Nature last year that the majority of potential dissidents had long since been driven out of the Czechoslovak scientific establishment. The surprising thing, he implied, was that there were any left at all.

Nevertheless, the number of signatures by scientists, although considerably smaller than that of writers, artists and workers, is large enough to demonstrate that Czech science is still not entirely Party-subservient. Moreover the presence of at least two scientists, Vladimir Lastusek, a nuclear engineer, and Ales Machacek, an agronomist, in prison for having distributed copies of the charter, suggests that the 1968 occupation of the academy cannot be taken as entirely symbolic of the future of Czechoslovak science.

Vera Rich 